\title{
Penerapan Model Pembelajaran Missouri Mathematics Project (MMP) untuk Meningkatkan Kemampuan Pemahaman Konsep Matematis Siswa pada Materi Segitiga
}

\author{
Rina Anggraini ${ }^{1}$, Citra Utami ${ }^{2}$, Rika Wahyuni ${ }^{2}$ \\ STKIP Singkawang, Singkawang, Indonesia \\ rinaalhasna@gmail.com ${ }^{1}$, citrautami1990@gmail.com ${ }^{2}$, Rikawahyuni142@gmail.com ${ }^{3}$
}

\author{
Keywords : \\ Pemahaman Konsep, Missouri \\ Mathematics Project (MMP)
}

\begin{abstract}
Penggunaan model pembelajaran bisa digunakan sebagai perangsang minat dan motivasi belajar peserta didik agar bisa terlibat secara aktif dalam pembelajaran. Adapun tujuan penelitian ini untuk meningkatkan kemampuan pemahaman konsep matematis siswa pada materi segitiga di kelas VII Madrasah Tsanawiyah Nurusshibyan Singkawang. Metode penelitian yang digunakan adalah metode quasy eksperimental dengan menggunakan dua kelas sebagai sampel. Penelitian dilakukan di Madrasah Tsanawiyah Nurusshibyan Singkawang tahun ajaran 2014/2015, kelas eksperimen adalah kelas VII A yang mendapatkan model pembelajaran Missouri Mathematics Project (MMP) dengan jumlah peserta didik sebanyak 32 orang dan kelas kontrol adalah kelas VII B yang mendapatkan model pembelajaran Langsung dengan jumlah peserta didik sebanyak 32 orang. Materi yang digunakan dalam penelitian ini adalah Segitiga. Berdasarkan hasil analisis statistik yang dilakukan diperoleh bahwa terdapat perbedaan peningkatan kemampuan pemahaman konsep akhir yang signifikan antara peserta didik yang mendapatkan model pembelajaran MMP dan model pembelajaran langsung. Adapun peningkatan kemampuan pemahaman konsep matematis peserta didik dari kedua kelas dikategorikan tinggi. Respon peserta didik terhadap model pembelajaran MMP menghasilkan respon baik dan keterlaksanaan aktivitas peserta didik terhadap model pembelajaran MMP dikategorikan baik.
\end{abstract}

\section{PENDAHULUAN}

Matematika masih dianggap sebagai pelajaran yang sulit sehingga berdampak pada rendahnya kemampuan pemahaman konsep matematis peserta didik. Salah satu upaya untuk mengatasi kesulitan peserta didik dalam memahami dan menyelesaikan masalah matematika adalah dengan mengajarkan matematika secara menarik dan terhubung dunia nyata. Suatu konsep disusun berdasarkan konsepkonsep sebelumnya dan akan menjadi dasar bagi konsep-konsep selanjutnya, sehingga pemahaman yang salah terhadap suatu konsep, akan berakibat pada kesalahan pemahaman terhadap konsep-konsep selanjutnya (Cahya, 2006). Penguasaaan konsep materi dalam matematika haruslah menjadi prioritas utama. Apabila siswa dapat mengusai suatu konsep dengan baik, maka berbagai macam variasi soal 
dan permasalahannya akan mudah diatasi. Hasil penelitian yang dilakukan Wong dan Evans (2007) menunjukkan bahwa pentingnya pemahaman konsep dapat menguatkan pengetahuan walaupun dengan tugas-tugas fraksi sederhana. Namun, untuk memahami konsep matematika memang bukanlah hal yang mudah. Hal ini didukung Ruseffendi (2005:156) yang mengatakan bahwa terdapat banyak anak-anak yang setelah belajar matematika bagian sederhanapun banyak yang tidak dipahami, banyak konsep yang dipahami secara keliru. Matematika dikenal sebagai ilmu yang sukar dipahami, tetapi banyak faktor yang dapat membantu memudahkan pemahaman matematika (Buyung, B., Nirawati, R., \& Kusumawati, I. (2016)). Pada akhirnya matematika dianggap sebagai mata pelajaran yang sulit, ruwet dan siswa enggan untuk mempelajarinya. Dengan kenyataan yang seperti itu mengakibatkan rendahnya pemahaman konsep matematis siswa.

Rendahnya pemahaman konsep matematis siswa Indonesia ini ditunjukkan pada hasil studi Internasional TIMSS (Trends in International Mathematics and Science Study). Hasil studi ini menunjukkan bahwa rata-rata skor pencapaian prestasi matematika siswa Indonesia pada tahun 2011 hanya 386. Sementara itu, standar rata-rata skor pencapaian prestasi matematika yang digunakan oleh TIMSS adalah 500 (Mullis, 2012).

Berdasarkan hasil penelitian yang dilakukan Triyanto dkk. (2012) diketahui bahwa pemahaman konsep matematika siswa masih sangat rendah. Penyebab kurangnya pemahaman konsep Matematika tersebut antara lain: (1) Pembelajaran yang mekanistik, sehingga siswa cenderung untuk menghafal rumus matematika, (2) Kurangnya media yang dapat meningkatkan kreatifitas siswa dalam memahami konsep dengan inkuiri, (3) Kurangnya variasi soal yang diberikan guru (guru lebih sering memberikan soal-soal rutin), tanpa modifikasi yang melatih kreatifitas anak.

Tingkat kemampuan pemahaman konsep matematis di alami oleh siswa Madrasah Tsanawiyah Nurusshibyan Singkawang yang masih belum bisa menunjukkan hasil yang memuaskan, khususnya pada materi segitiga kelas VII. Hal ini diperoleh dari hasil observasi dan prariset yang dilakukan oleh peneliti. Hasil observasi yang peneliti lakukan dengan melihat keadaan siswa dalam proses belajar matematika dan penyelesaian soal yang guru berikan.

Terlihat bahwa siswa dalam pelajaran matematika dengan kondisi yang masih belum siap menerima pelajaran, walaupun guru telah menjelaskan dan memberikan contoh dari materi yang dipelajari. Hanya beberapa siswa yang mendengarkan dan memperhatikan guru dalam menjelaskan. Ketika beberapa siswa sudah paham, ternyata masih ada siswa yang kurang begitu paham sehingga guru harus menjelaskan kembali pada seluruh siswa sebelum melanjutkan pada materi selanjutnya. Kenyataan seperti itu merupakan pemahaman konsep siswa yang tidak merata.

Dalam penyelesaian soal yang guru berikan sebagian besar penyelesaian dilakukan siswa hanya sekedar menyelesaikan dan mengerjakan tanpa memahami masalah, memperhatikan rencana penyelesaian dan pengecekan hasil akhir. Selain itu ada beberapa siswa yang senang menyalin pekerjaan milik siswa lainnya. Dengan kenyataan seperti itu terlihat bahwa kurangnya aktivitas yang dilakukan siswa.

Hasil wawancara dengan Kepala Sekolah, dinyatakan bahwa dalam proses pembelajaran di kelas guru sudah menggunakan berbagai metode sebagai upaya meningkatkan hasil belajar. Metode tersebut diantaranya metode ceramah, tanya jawab dan mengulang kembali materi yang telah diberikan. Tetapi masih ada siswa yang menganggap bahwa pelajaran matematika membosankan.

Hasil wawancara dengan guru mata pelajaran matematika, dinyatakan bahwa materi segitiga siswa cenderung memiliki kesulitan dalam menentukan sifat-sifat segitiga, sehingga hal ini berdampak kekeliruan dalam menentukan keliling dan luas segitiga. Pernyataan tersebut disetujui oleh beberapa siswa dan siswi kelas VIII yang sebelumnya sudah mempelajari materi itu, bahwa dalam proses pembelajarannya materi tersebut terlihat mudah dimengerti tetapi ketika guru memberikan soal-soal berupa pemahaman konseptual siswa mengalami kesulitan dalam menganalisa dan menemukan jawabannya. 
Hasil prariset yang dilakukan peneliti di Madrasah Tsanawiyah Nurusshibyan Singkawang dengan memberikan soal yang memuat indikator pemahaman konsep matematis siswa pada materi segitiga di kelas VII. Peneliti memberikan 3 soal dengan 4 indikator pemahaman kosep matematis yaitu; (1) menyatakan ulang suatu konsep; (2) memberikan contoh dan non contoh dari konsep; (3) mengaplikasikan konsep atau algoritma pemecahan masalah (4) menggunakan, memanfaatkan, dan memilih prosedur atau operasi tertentu; kepada 64 orang siswa dan hasilnya kemampuan pemahaman konsep matematis siswa masih sangat rendah untuk keempat indikator tersebut.

Berdasarkan hasil analisis dari prariset yang diberikan bahwa (1) terdapat 12 siswa $(18,75 \%)$ yang dapat menjawab, menjelaskan, dan menyatakan ulang jenis-jenis segitiga dan 52 siswa $(81,25 \%)$ yang tidak dapat menjawab, menjelaskan dan menyatakan ulang konsep jenis-jenis segitiga, (2) terdapat 24 siswa $(37,50 \%)$ yang dapat memberikan contoh dan non contoh dari konsep dan 40 siswa $(62,50 \%)$ yang tidak dapat memberikan contoh dan non contoh dari konsep, (3) terdapat 16 siswa (25\%) yang dapat menjawab dan 48 siswa (75\%) yang tidak dapat mengaplikasikan konsep atau algoritma pemecahan masalah, (4) terdapat 22 siswa $(34,37 \%)$ yang dapat menjawab dan 42 siswa $(65,63 \%)$ yang tidak dapat menggunakan, memanfaatkan, dan memilih prosedur atau operasi tertentu.

Untuk mengatasi masalah tersebut, maka diperlukan model pembelajaran yang tepat. Salah satu model pembelajaran yang diharapkan mampu memantapkan pemahaman konsep siswa adalah Missouri Mathematics Project (MMP). Model pembelajaran MMP menjadi pilihan karena model ini dirancang untuk meningkatkan kemampuan siswa dalam memahami konsep, menyelesaikan soal-soal, dan memecahkan masalah-masalah matematika hingga pada akhirnya peserta didik mampu mengkonstruksikan jawaban mereka sendiri karena banyaknya pengalaman yang dimiliki peserta didik dalam menyelesaikan soal-soal latihan (Krismanto, 2003:11). Oleh karena itu,tujuan dari penelitian ini adalah untuk menerapkan model pembelajaran MMP untuk melihat peningkatan kemampuan pemahaman konsep siswa kelas VII di MTs Nurusshibyan Singkawang. Dalam penelitian ini juga dilihat apakah terdapat perbedaan peningkatan pemahaman konsep siswa antara kelas yang mendapat pembelajaran MMP dengan kelas yang mendapat model pembelajaran langsung, melihat persentase keterlaksanaan model MMP, melihat persentase aktivitas siswa pada model MMP dan melihat respon siswa terhadap model MMP dalam pembelajaran matematika.

\section{METODE}

Metode yang digunakan dalam penelitian ini adalah metode eksperimen dengan Quasi Experimental Design. Adapun rancangan penelitian yang digunakan yaitu Pretest-Posttest Control Group Design. Tahap pertama dilakukan pengukuran dengan pretest, kemudian tahap kedua dikenakan perlakuan (treatment), dan tahap ketiga diakhiri dengan posttest. Populasi dalam penelitian ini adalah seluruh siswa kelas VII MTs Nurrushibyan Singkawang. Sampel dalam penelitian ini terdiri dari 2 kelas, yaitu kelas VII A sebagai kelas yang diberi pembelajaran MMP (kelas eksperimen) dan kelas VII B sebagai kelas yang diberi model pembelajaran langsung (kelas kontrol). Adapun teknik pengambilan sampel yang digunakan dalam penelitian ini adalah probability sampling. Menurut Sugiyono (2013) probability sampling adalah teknik pengambilan sampel yang memberikan peluang yang sama bagi setiap unsur (anggota) populasi untuk dipilih menjadi anggota sampel. Cara tersebut dilakukan karena populasi dianggap homogen dengan terlebih dahulu dilakukan uji homogenitas data.

Teknik pengumpulan data yang dipergunakan dalam penelitian ini sebagai berikut: (a) Teknik pengukuran untuk melihat perbedaan peningkatan kemampuan pemahaman konsep siswa antara kelas eksperimen dengan kelas kontrol, (b) Teknik observasi langsung untuk melihat aktivitas siswa dan keterlaksanaan model pembelajaran pada kelas eksperimen. Instrumen yang digunakan untuk teknik pengukuran berupa soal kemampuan pemahaman konsep matematis dan lembar observasi untuk teknik observasi langsung, (c) Teknik komunikasi tidak langsung untuk melihat respon siswa berupa angket yang disebarkan kepada siswa. Sebelum soal digunakan dalam penelitian, terlebih dahulu diujicobakan yang selanjutnya dianalisis. Berdasarkan hasil ujicoba di MTs Al-Hidayah Singkawang diperoleh informasi bahwa soal pre-test, post-test, Rencana Pelaksanaan Pembelajaran (RPP), dan 
lembar observasi valid untuk digunakan dalam penelitian. Selain itu soal kemampuan pemahaman konsep matematis juga dinyatakan cukup reliabilitas untuk digunakan dalam penelitian dengan tingkat kesukaran sedang.

Teknik analisis data yang digunakan sebagai berikut: (1) untuk menjawab sub masalah pertama: uji NGain digunakan untuk melihat peningkatan kelas eksperimen dan kelas kontrol, lalu menguji perbedaan peningkatan kelas eksperimen dengan kelas kontrol menggunakan T-Test independent. Sebelum uji T-Test Korelasi digunakan maka dianalisis terlebih dahulu uji normalitas dan homogenitas. Uji normalitas menggunakan rumus chi-kuadrat sedangkan homogenitas menggunakan uji varians, (2) Untuk menjawab sub masalah kedua tentang keterlaksanaan model pembelajaran MMP pada materi segitiga akan dilakukan pengolaan data dengan cara mencari persentase keterlaksanaan model pembelajaran MMP terhadap skor yang dibuat berdasarkan skala Likert. (3) Untuk menjawab sub masalah ketiga tentang aktivitas model pembelajaran MMP pada materi segitiga akan dilakukan pengolaan data dengan cara mencari persentase aktivitas model pembelajaran MMP terhadap skor yang dibuat berdasarkan skala Likert. (4) Untuk menjawab sub masalah keempat tentang respon model pembelajaran MMP pada materi segitiga akan dilakukan pengolaan data dengan cara mencari persentase respon model pembelajaran MMP terhadap skor yang dibuat berdasarkan skala Likert.

\section{HASIL DAN PEMBAHASAN}

\section{Kemampuan Pemahaman Konsep Matematis Siswa}

Adapun rangkuman hasil pre-test dan post-test kelas ekperimen dan kelas kontrol ditampilkan dalam Tabel 1.

Tabel 1. Nilai Pre-test dan Post-test Kelas Eksperimen dan Kelas Kontrol

\begin{tabular}{lcccc}
\hline \multirow{2}{*}{ Keterangan } & \multicolumn{2}{c}{ Kelas Eksperimen } & \multicolumn{2}{c}{ Kelas Kontrol } \\
\cline { 2 - 5 } & Pretest & Posttest & Pretest & Posttest \\
\hline Rata-rata & 39,07 & 75,50 & 38,81 & 61,18 \\
Standar Deviasi & 6,76 & 13,08 & 6,72 & 10,60 \\
\hline
\end{tabular}

Berdasarkan data dalam Tabel 1 tersebut dapat dikatakan bahwa terjadi peningkatan kemampuan pemahaman konsep matematis siswa pada kelas eksperimen dan kelas kontrol. Untuk melihat besarnya peningkatannya, maka dilakukan uji N-Gain yang hasilnya disajikan dalam Tabel 2.

Tabel 2. Nilai N-Gain Kelas Eksperine dan Kontrol

\begin{tabular}{lcc}
\hline \multicolumn{1}{c}{ Kelas } & Nilai N-Gain & Kriteria \\
\hline Eksperimen & 0,60 & Sedang \\
Kontrol & 0,36 & Sedang \\
\hline
\end{tabular}

Untuk melihat perbedaan peningkatan kemampuan pemahaman konsep matematis antara siswa di kelas eksperimen dan kelas kontrol dilakukan pengujian hipotesis dengan t-test independent dengan terlebih dahulu data dinyatakan normal dan homogen berdasarkan hasil analisis data diketahui bahwa nilai $\boldsymbol{t}_{\text {hitung }}$ yaitu 8,625 dan nilai tabel dengan taraf signifikan $(\alpha) 5 \%$ yaitu 2,042. Dari data tersebut maka $\boldsymbol{t}_{\text {hitung }}>\mathbf{t}_{\text {tabel }}$ atau 8,625 > 2,042 yang berarti bahwa $\mathrm{H}_{0}$ ditolak dan $\mathrm{H}_{\mathrm{a}}$ di terima. Maka dapat disimpulkan bahwa terdapat perbedaan peningkatan kemampuan pemahaman konsep matematis siswa antara kelas eksperimen dengan kelas kontrol.

\section{Keterlaksanaan Model Pembelajaran MMP}

Berdasarkan lima tahap pembelajaran yang dimiliki MMP dikembangkan menjadi 20 indikator yang 
akan di observasi. Adapun ringkasan data hasil observasi pertemuan pertama dan kedua dapat dilihat pada Tabel 3.

Tabel 3. Keterlaksanaan Proses Pembelajaran

\begin{tabular}{ccc}
\hline \multirow{2}{*}{$\begin{array}{c}\text { Pembelajaran Model } \\
\text { MMP }\end{array}$} & \multicolumn{2}{c}{ Pertemuan ke- } \\
\cline { 2 - 3 } & 1 & 2 \\
\cline { 2 - 3 } & $72 \%$ & $89 \%$ \\
\hline Kriteria & Baik & Sangat Baik \\
\hline
\end{tabular}

Dari Tabel 3 dapat diketahui bahwa terdapat peningkatan keterlaksanaan model pembelajaran MMP dari pertemuan pertama ke pertemuan kedua dengan selisih $17 \%$.

\section{Aktivitas Belajar Siswa dalam Model Pembelajaran MMP}

Berdasarkan enam kategori pembelajaran yang dimiliki MMP dikembangkan menjadi 18 indikator yang akan di observasi. Adapun ringkasan data hasil observasi pertemuan pertama dan kedua dapat dilihat pada Tabel 4.

Tabel 4. Aktivitas Belajar Siswa Proses Pembelajaran MMP

\begin{tabular}{lcc}
\hline \multicolumn{1}{c}{ Pertemuan } & Perilaku Siswa Aktif & Perilaku Siswa Pasif \\
\hline Pertama & $78,01 \%$ & $22 \%$ \\
Kedua & $93,74 \%$ & $8,21 \%$ \\
\hline \multicolumn{1}{c}{ Rata-rata } & $85,87 \%$ & $15,10 \%$ \\
\hline Kategori & Sangat Baik & Kurang \\
\hline
\end{tabular}

Dari Tabel 4 dapat diketahui bahwa terdapat peningkatan perilaku siswa aktif dan penurunan perilaku siswa pasif terhadap model pembelajaran MMP dari pertemuan pertama ke pertemuan kedua dengan selisih $70,77 \%$.

\section{Respon Siswa dalam Model Pembelajaran MMP}

Berdasarkan dua kategori pembelajaran yang dimiliki MMP dikembangkan menjadi 20 indikator yang akan di observasi. Adapun ringkasan data hasil observasi pertemuan pertama dan kedua dapat dilihat pada Tabel 5.

Tabel 5. Respon Siswa Proses Pembelajaran MMP

\begin{tabular}{ccc}
\hline \multicolumn{1}{c}{ Aspek } & Persentase & Kategori \\
\hline Sikap siswa terhadap matematika & $61,77 \%$ & Cukup \\
Sikap siswa terhadap model pembelajaran MMP & $77,90 \%$ & Baik \\
\hline Rata-rata & $69,83 \%$ & Baik \\
\hline
\end{tabular}

Dari Tabel 5 dapat diketahui bahwa terdapat respon siswa positif terhadap model pembelajaran MMP dari aspek satu dan aspek dua dengan rata-rata $69,83 \%$.

Dari hasil penelitian menunjukkan bahwa pembelajaran matematika menggunakan model pembelajaran MMP pada materi segitiga yang diterapkan dikelas VII A dapat meningkatkan kemampuan pemahaman konsep matematis siswa secara signifikan. Ini dapat dilihat dari hasil tes kemampuan pemahaman konsep matematis siswa setelah diberikan pembelajaran dengan menggunakan model pembelajaran MMP yang lebih tinggi dari pada hasil tes kemampuan pemahaman konsep matematis siswa dengan metode pembelajaran langsung. Terjadinya peningkatan kemampuan pemahaman konsep siswa di dukung dengan keterlaksanaan model pembelajaran MMP, aktivitas belajar siswa dengan model pembelajaran MMP, dan respon siswa terhadap model pembelajaran MMP. 


\section{SIMPULAN DAN SARAN}

Berdasarkan hasil analisis data dapat disimpulkan bahwa penerapan model pembelajaran MMP dapat meningkatkan kemampuan pemahaman konsep matematis siswa pada materi segitiga di kelas VII MTs Nurusshibyan Singkawang. Hal tersebut ditunjukkan dengan terdapat perbedaan peningkatan kemampuan pemahaman konsep matematis antara siswa yang diberi pembelajaran model MMP dengan siswa yang diberi pembelajaran langsung, model MMP terlaksana sangat baik dalam pembelajaran matematika dengan persentase $72 \%$ untuk pertemuan pertama dan $89 \%$ untuk pertemuan kedua, aktivitas belajar siswa pada model pembelajaran MMP memiliki dua perilaku untuk pertemuan pertama perilaku siswa aktif dengan persentase $78,01 \%$ dan $22 \%$ perilaku siswa pasif, untuk pertemuan kedua perilaku siswa aktif dengan persentase $93,74 \%$ dan $8,21 \%$ perilaku siswa pasif, serta respon siswa positif terhadap model pembelajaran MMP dengan persentase 69,83\%

Berdasarkan pembahasan dan hasil penelitian serta kesimpulan yang telah didapat, terdapat beberapa saran dari peneliti untuk penyempurnaan penelitian sejenis selanjutnya. Beberapa saran tersebut yaitu diupayakan agar siswa lebih memperhatikan penjelasan guru selama proses belajar mengajar yang berlangsung, dan model pembelajaran MMP yang diterapkan pada materi segitiga dapat diterapkan juga pada materi matematika yang lainnya.

\section{DAFTAR PUSTAKA}

Buyung, B., Nirawati, R., \& Kusumawati, I. (2016). Pengaruh Strategi Pembelajaran Inkuiri (SPI) Terhadap Kemampuan Pemahaman Konsep Siswa Kelas VIII SMP Negeri 18 Singkawang. JPMI (Jurnal Pendidikan Matematika Indonesia), 1(2), 87-90.

Cahya, A. P. (2006). Memahami Konsep Matematika Secara Benar dan Menyajikannya dengan Menarik. Jakarta: Departemen Pendidikan Nasional.

Krismanto, A. (2003). Beberapa Teknik, Model, dan Strategi Dalam Pembelajaran Matematika. Yogyakarta: Departemen Pendidikan Nasional Direktorat Jendral Pendidikan Dasar dan Menengah Pusat Pengembangan Penataran Guru (PPPG) Matematika.

Mullis, V. S. (2012). TIMSS 2011 Internasional Results in Mathematics. Jurnal Program Studi Pendidikan Matematika, 1(2).

Ruseffendi. (2005). Dasar-dasar Penelitian Pendidikan dan Bidang Non-Eksakta Lainnya. Bandung: Tarsito.

Sugiyono. (2013). Metode Penelitian Pendidikan Pendekatan Kuantitatif, Kualitatif, dan R\&D. Bandung: Alfabeta.

Triyanto, dkk (2012). Analisis Pemahaman Konsep Matematika Dan Implementasinya Dalam Pengembangan Model Pembelajaran Matematika Siswa Sekolah Menengah Pertama di Kabupaten Klaten. Jurnal Fakultas Keguruan dan Ilmu Pendidikan, 1(1).

Wong dan Evans. (2007). Students' Conceptual Understanding Of Equivalent Fractions. Jurnal Program Studi Pendidikan Matematika, 7(12). 